\title{
KAJIAN PENGGUNAAN SERASAH DAUN KAKAO UNTUK SUBTITUSI SERBUK GERGAJI DAN DEDAK PADI SEBAGAI MEDIA TANAM JAMUR TIRAM PUTIH (Pleurotus ostreatus)
}

\section{[Utilizing Study of Cocoa Leaf Litter for Substitution Sawdust and Rice Bran as White Oyster Mushroom Growing Media(Pleurotus ostreatus)]}

\author{
Abd. Rahman Razak ${ }^{\left.1^{*}\right)}$, Susanti ${ }^{1)}$, Nurhaeni ${ }^{1)}$, Muh. Alwi ${ }^{2)}$ \\ 1) Jurusan Kimia FMIPA Universitas Tadulako, Palu \\ Jl. Soekarno Hatta, Kampus Bumi Tadulako Tondo Palu, Telp. 0451- 422611 \\ 2) Jurusan Biologi FMIPA Uiversitas Tadulako, Palu \\ Jl. Soekarno Hatta, Kampus Bumi Tadulako Tondo Palu, Telp. 0451- 422611
}

Diterima 4 Desember 2016, Disetujui 18 Februari 2017

\begin{abstract}
Has done research on the study of the use of cocoa leaf litter for substitution sawdust and rice bran as a growing medium white oyster mushroom (Pleurotus ostreatus). This study aims to determine the ability of the cocoa leaf litter in substitute sawdust and rice bran as oyster mushroom media and to determine the nutrient value of the conversion of media into fruiting bodies of oyster mushrooms. Treatment comparison of leaf litter cocoa (SDK), sawdust (SG) and rice bran (DP) there are seven various ie first treatment / standard (SDK: $0 \mathrm{~kg}$, SG: $5 \mathrm{~kg}$, DP: $3 \mathrm{~kg}$ ), second (SDK: $1,5 \mathrm{~kg}$, SG: $5 \mathrm{~kg}$, DP: $1.5 \mathrm{~kg}$ ), third (SDK: $3 \mathrm{~kg}$, SG: $5 \mathrm{~kg}$, DP: $0 \mathrm{~kg}$ ), fourth (SDK: $2.5 \mathrm{~kg}$, SG: $2.5 \mathrm{~kg}$ DP: $3 \mathrm{~kg}$ ), fifth (SDK: $5 \mathrm{~kg}$, SG: $3 \mathrm{~kg}$, DP: $0 \mathrm{~kg}$ ), sixth (SDK: $5 \mathrm{~kg}, \mathrm{SG}: 1.5 \mathrm{~kg}$, DP: $1.5 \mathrm{~kg}$ ), and seventh (SDK: $5 \mathrm{~kg}$, SG: $0 \mathrm{~kg}, \mathrm{DP}: 3 \mathrm{~kg}$ ). The results showed that both treatments are best treated with a total weight of $181.122 \mathrm{~g}$ fruit.
\end{abstract}

Keywords: cocoa leaf litter, white oyster mushroom.

\begin{abstract}
ABSTRAK
Telah dilakukan penelitian tentang kajian penggunaan serasah daun kakao untuk subtitusi serbuk gergaji dan dedak padi sebagai media tanam jamur tiram putih (Pleurotus ostreatus).Penelitian ini bertujuan untuk mengetahui kemampuan serasah daun kakao dalam mensubtitusi serbuk gergaji dan dedak padi sebagai media jamur tiram dan untuk mengetahui nilai konversi nutrien media menjadi tubuh buah jamur tiram. Perlakuan perbandingan serasah daun kakao (SDK), serbuk gergaji (SG) dan dedak padi (DP) ada 7 variasai yaitu perlakuan pertama/ standar (SDK: $0 \mathrm{~kg}$, SG: $5 \mathrm{~kg}$, DP: $3 \mathrm{~kg}$ ), kedua (SDK: $1,5 \mathrm{~kg}$, SG: $5 \mathrm{~kg}$, DP: $1,5 \mathrm{~kg}$ ), ketiga (SDK: $3 \mathrm{~kg}$, SG: $5 \mathrm{~kg}$, DP: $0 \mathrm{~kg}$ ), keempat (SDK: 2,5 kg, SG: 2,5 kg, DP: $3 \mathrm{~kg}$ ), kelima (SDK: $5 \mathrm{~kg}$, SG: $3 \mathrm{~kg}$, DP: $0 \mathrm{~kg}$ ), keenam (SDK: $5 \mathrm{~kg}$, SG: 1,5 $\mathrm{kg}$, DP: $1,5 \mathrm{~kg}$ ), dan yang ketujuh (SDK: $5 \mathrm{~kg}$, SG: $0 \mathrm{~kg}$, DP: $3 \mathrm{~kg}$ ). Hasil yang diperoleh menunjukkan bahwa perlakuan kedua adalah perlakuan terbaik dengan total berat tubuh buah sebesar $181,122 \mathrm{~g}$.
\end{abstract}

Kata kunci :serasah daun kakao, jamur tiram putih. 


\section{LATAR BELAKANG}

Jamur tiram putih merupakan salah satu jenis jamur yang mudah dibudidayakan di daerah tropik dan subtropik. Oleh karena kandungan gizi yang tinggi pada jamur tiram sehingga sering menjadi pilihan untuk dikonsumsi. Permintaan pasar yang tinggi terhadap jamur tiram sehingga menjadikannya sebagai komoditas yang cukup potensial untuk dipasarkan, Akan tetapi, produksi jamur tiram masih rendah, sehingga peluang untuk membudidayakannya sangat terbuka (Chazali \& Putri, 2009).

Indonesia memiliki beberapa jenis jamur yang dapat dikomsumsi, diantaranya jamur merang, champignom, morel, lingzhi, emas, kuping, payung termasuk jamur tiram (Pleorotus sp.). Direktorat Jenderal Hortikultura Departemen Pertanian melaporkan bahwa jamur tiram mengandung protein rata-rata 3,5-4\% dari berat basah. Kandungan tersebut dua kali lipat lebih tinggi dibandingkan asparagus dan kubis. Berdasarkan berat keringnya, kandungan protein jamur tiram adalah $19-35 \%$. Kandungan protein tersebut lebih tinggi daripada komoditas lain, seperti beras $7.3 \%$, gandum $13.2 \%$, dan susu sapi $25.2 \%$ (Suriawiria, 1986).

Jamur tiram memiliki nilai gizi yang tinggi, diantaranya protein 5,49\%, karbohidrat $59 \%$, serat $1,56 \%$, lemak $0,1 \%$. Dalam $100 \mathrm{~g}$ jamur tiram segar memiliki kandungan besi $1,9 \mathrm{mg}$, fosfor $17,0 \mathrm{mg}$, kalsium $8,9 \mathrm{mg}$, vitamin $\mathrm{B} 0,15 \mathrm{mg}$, vitamin B2 $0,75 \mathrm{mg}$, vitamin C $12,4 \mathrm{mg}$, dan menghasilkan 45,65 kalori. Aroma jamur tiram putih (pleurotus ostreatus) sangat khas karena mengandung muskorin yang berkhasiat untuk kesehatan. Jamur ini tumbuh secara saprofit pada kayu yang sudah lapuk (Wahyudi, 2002). Jamur tiram juga dapat tumbuh pada serbuk jerami dan gergaji (Ambarwati, 1991), ataupun pada bahan organik lain yang mengandung selulosa dengan nilai $\mathrm{C} / \mathrm{N}>50$ (Zadrazil, 1978).

Jamur tiram putih memerlukan suhu $22-28^{\circ} \mathrm{C}$ dan kelembapan $60-80 \%$ pada fase pembentukan miselium dan memerlukan suhu $16-22^{\circ} \mathrm{C}$ dan kelembapan $80-90 \%$ pada fase pembentukan tubuh buah dengan kadar oksigen cukup dan cahaya matahari sekitar 10\% (Parjimo \& Andoko, 2007).

Harga dedak yang semakin meningkat dikarenakan harga beras yang semakin tinggi, akan tetapi dedak yang juga menjadi kebutuhan utama dari peternak yang membuat pakan campuran sendiri. Akibatnya timbul persaingan antara petani jamur dengan peternak dalam hal pemenuhan kebutuhan dedak. Oleh karena harga yang semakin tinggi dan jumlah yang semakin sedikit, membuat para petani jamur tiram menemui kendala untuk memenuhi kebutuhan dedak untukpada prose produksi jamur. Pada akhirnya keuntungan petani menjadi lebih rendah dikarenakan biaya produksi yang semakin tinggi, sebalikynya harga jual jamur tetap. Hal ini mendorong penulis untuk mengadakan penelitian mengenai kajian 
penggunaan serasah daun kakao untuk subtitusi serbuk gergaji dan dedak padi sebagai media tanam jamur tiram putih (Pleurotus ostreatus). Penelitian ini diharapkan bisa membantu petani jamur tiram putih untuk mengatasi permasalahan proporsi dedak pada media tanam sehingga pertumbuhan jamur tiram tetap bagus dengan proporsi dedak yang seminimal mungkin.

Tanaman kakao (Theobroma cacao, L) menjadi salah satu komoditas andalan perkebunan di Indonesia. Hasil tanaman kakao dapat memberikan devisa cukup besar, sumber pendapatan, penciptaan lapangan kerja, mendorong pengembangan dan pengolahan sumber daya alam wilayah, serta pengembangan agebisnis dan argo industri. Indonesia menjadi penghasil kakao terbesar ketiga di dunia setelah Ghana dan Pantai Gading. Indonesia memberikan kontribusi sekitar $12 \%$ terhadap produksi kakao dunia (Sulistyowati dkk, 2003).

Usaha budidaya jamur tiram (Pleurotus ostreatus) berpeluang untuk dikembangkan.Pengetahuan masyarakat tentang khasiat jamur tiram semakin bertambah seiring dengan kemajuan ilmu dan teknologi hayati. Serasah daun kakao adalah limbah yang tersedia melimpah secara berkelanjutan dan merupakan sumber daya hayati selulosa yang perlu dikaji menjadi bahan baku substrat dan biokonversi menjadi tubuh buah jamur tiram.

\section{METODE PENELITIAN}

\section{Bahan dan Peralatan}

Bahan dasar yang digunakan dalam penelitian ini adalah serasah daun kakao, serbuk gergaji, dedak padi, $\mathrm{CaCO}_{3}$, gips, eter, $\mathrm{H}_{3} \mathrm{BO}_{4}, \mathrm{H}_{2} \mathrm{SO}_{4}$.

Peralatan yang digunakan dalam penelitian ini adalah blender, timbangan, baskom, pengaduk, labu kjeldahl, alat destilasi, buret, alat soxhlet, neraca analitik, desikator, oven, klem dan statif, pipet, tabung reaksi, watarbath, spektrofotometer dan alat-alat gelas yang umum digunakan di laboratorium kimia.

\section{Prosedur Kerja \\ Persiapan Bahan}

Bahan yang harus dipersiapkan diantaranya serbuk gergaji, serasah daun kakao, dedak padi, kapur $\left(\mathrm{CaCO}_{3}\right)$, gips dan air.

\section{a. Pembersihan dan pengayakan media}

Untuk daun kakao dibersihkan (dicuci) terlebih dahulu setelah itu dijemur/dikeringkan, kemudian diayak bersama dengan Serbuk kayu dengan menggunakan ukuran ayakan 8 mess 2,36 mm. tujuan dari pengayakan yaitu untuk memperoleh ukuran media yang seragam.

\section{b. Pencampuran media}

Bahan-bahan yang telah ditimbang sesuai dengan perlakuan dicampur, selanjutnya ditambahan dengan air sekitar 60 - $65 \%$ atau bila kita kepal serbuk tersebut menggumpal tapi tidak keluar air. Hal ini menandakan kadar air sudah cukup. 


\section{c. Pengomposan}

Pengomposan adalah proses pelapukan bahan yang dilakukan dengan cara membumbun campuran media kemudian menutupinya dengan karung selama 1 malam.

\section{d. Pembungkusan(pengisian baglog)}

Pembungkusan menggunakan plastik baglog yang tahan panas dengan ukuran yang dibutuhkan yaitu tiap 1 baglog berisi 1 $\mathrm{Kg}$ media.Cara membungkus adalah dengan memasukkan media ke dalam plastik kemudian dipukul/ditumbuk sampai padat dengan botol atau menggunakan filler (alat pemadat).

\section{e. Sterilisasi}

Sterilisasi dilakukan dengan menggunakan tungku permanen dan drum sebagai wadah yang bertujuan menginaktifkan mikroba, bakteri, kapang, maupun khamir yang dapat mengganggu pertumbuhan jamur yang ditanam. Sterilisasi dilakukan pada suhu $100-150^{\circ}$ C selama 3 jam.Kemudian didinginkan selama 1 hari.Sebelum pemberian bibit.

\section{f. Inokulasi (Pemberian Bibit)}

Inokulasi adalah kegiatan memasukan bibit jamur ke dalam media jamur yang telah disterilisasi. Baglog yang sudah didinginkan selama 1 malam setelah sterilisasi, kemudian kita ambil dan ditanami bibit diatasnya dengan menggunakan spatula, 1 botol bibit $F_{2}$ menjadi 5 baglog (tiap baglog diisi sebanyak 1 tutup botol bibit $F_{2}$ ). kemudian pada bagian atas baglog dipasang cincinya kembali lalu ditutupi menggunakan kertas dan diikat dengan karet gelang.

\section{g. Inkubasi (masa pertumbuhan miselium) Jamur Tiram \\ Inkubasi Jamur Tiram dilakukan} dengan cara menyimpan baglog pada ruangan inkubasi dengan suhu ruangan $25-28^{\circ} \mathrm{C}$. Inkubasi dilakukan hingga seluruh media berwarna putih merata memenuhi baglog, biasanya media akan tampak putih merata antara 30 - 40 hari, setelah baglog penuh dengan miselia akan dipindahkan ke kumbung dengan suhu 20$24^{\circ} \mathrm{C}$, untuk pemeliharan tubuh buah.

\section{h. Panen dan Pengamatan}

Pengamatan pertumbuhan miselia memenuhi baglog. Sedangkan untuk pengamatan tubuh buah dilakukan setelah tubuh pertama sampai tubuh buah yang ke-3.

\section{Analisis Kadar Air}

Cawan porselen dikeringkan pada suhu $105^{\circ} \mathrm{C}$ selama 1 jam, didinginkan dan ditimbang.Sebanyak $5 \mathrm{~g}$ sampel dimasukkan ke dalam cawan porselen, lalu dimasukkan ke dalam oven bersuhu $105^{\circ} \mathrm{C}$ sampai tercapai bobot konstan. Kadar air dihitung berdasarkan rumus :

$$
\text { Kadar Air (\%) }=\frac{(B-A)}{\text { Berat Sampel }} \times 100 \%
$$

Keterangan :

$\mathrm{A}=$ berat cawan + sampel kering $(\mathrm{g})$

$\mathrm{B}=$ berat cawan + contoh basah $(\mathrm{g})$

\section{Analisis Protein}

Sampel sebanyak 0,5 g ditambah kurang lebih $1 \mathrm{~g}$ katalis ditambah $10 \mathrm{ml}$ $\mathrm{H}_{2} \mathrm{SO}_{4}(p)$ diges pada kejeldhalterm hingga 
jernih.Hasil destruksi (diges) dipasang pada alat vapodest, nyalakan vapodest dan titrator bila vapodest memberikan tanda standbay tekan execution dengan otomatis alat akan menambahkan $\mathrm{H}_{2} \mathrm{O}, \mathrm{NaOH}$, dan pada tampungan destilat $\mathrm{H}_{3} \mathrm{BO}_{3}$. Otomatis alat vapodest mendestilasi, dan otomatis pula akan berhenti bila sudah terdestilasi dan langsung menitrasi secara otomatis sesuai perubahan warna yang terjadi, otomatis pula akan muncul hasil titrasinya.

Persamaan:

$$
\% \text { Protein }=\frac{\mathrm{VxN} \times 0,014 \times 6,38}{Y} \times 100
$$

Keterangan:

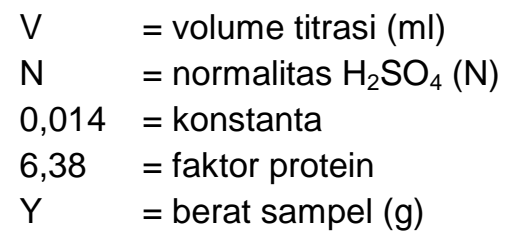

\section{Analisis Lemak (Zuhra dkk, 2012)}

Sampel dibungkus dangan kertas saring yang telah ditimbang beratnya sampai konstan.Bungkusan sampel kemudian dimasukkan ke dalam sokhlet.Labu diisikan dengan eter dengan volume sekitar setengah bagian dari volume labu. Proses ekstraksi berlangsung dalam jangkauan suhu $40-60^{\circ} \mathrm{C}$. Proses ini dihentikan apabila eter didalam sokhlet sudah jernih. Kertas saring yang berisi sampel diangkat dan dikeringkan di dalam oven pada suhu $100-110^{\circ} \mathrm{C}$ selama satu jam.Sampel kemudian dikeluarkan dan didinginkan di dalam desikator kemudian ditimbang beratnya sampai konstan.

Persamaan:

$$
\% \text { kadar Lemak }: \frac{B-(C-A)}{B} \times 100 \%
$$

Dimana :

$A=$ bnerat kertas saring $(g)$

$\mathrm{B}=$ berat bahan awal $(\mathrm{g})$

$C=A+B$ setelah dioven $(g)$

Analisis Kadar Abu (Andarwulan dkk, 2011)

Sampel yang telah diuapkan airnya dimasukkan ke dalam tanur bersuhu $600^{\circ} \mathrm{C}$. Proses penguapan dilakukan sampai semua bahan berubah warna menjadi abu-abu, kemudian contoh ditimbang. Kadar abu dihitung dengan rumus :

$$
\text { Kadar Abu (\%)= } \frac{\text { Berat Abu }}{\text { Berat Sampel }} \times 100 \%
$$

\section{Analisis Karbohidrat (Andarwulan dkk, 2011)}

Pengukuran kadar karbohidrat total dalam sampel dihitung berdasarkan perhitungan (dalam \%) : \% karbohidrat = $100 \%-\%$ (protein + lemak + abu + air).

\section{HASIL DAN PEMBAHASAN}

\section{Media Tanam Jamur Tiram berdasarkan Waktu Panen (hari)}

Lamanya waktu panen yang diperlukan dalam pertumbuhan jamur tiram putih sangat berfariasi. Pada panen perdana yang paling cepat tumbuh sebagaimana yang tersaji pada Gambar 1, yaitu perlakuan M3 (SDK $3 \mathrm{~kg}$, SG $5 \mathrm{~kg}$ tanpa dedak padi) dengan rata-rata waktu yang di perlukan untuk tumbuh selama 3 kali panen totalnya adalah selama 27,7 hari, dimana rata-rata waktu yang diperlukan untuk tumbuh pada panen pertama yaitu 11,7 hari, panen kedua yaitu 
8,7 hari dan untuk panen ketiga yaitu 7,3 hari.

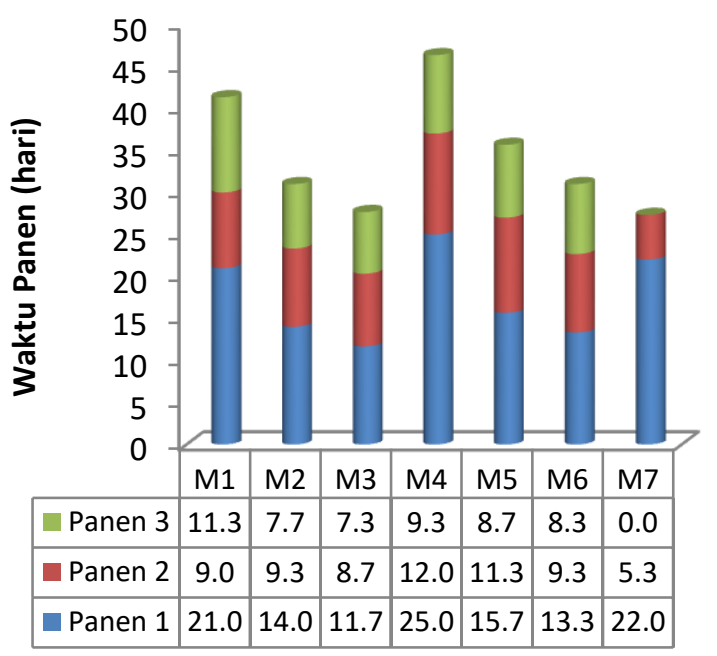

Media Tanam

Gambar 1. Waktu panen jamur tiram putih berdasarkan perlakuan media tanam.

Pada perlakuan M7 (campuran media tanpa serbuk gergaji di mna serasah daun kakao $5 \mathrm{~kg}$ dan $3 \mathrm{~kg}$ dedak padi) juga memerlukan waktu yang singkat untuk total rata-rata pertumbuhan tapi, hanya dengan satu dan dua kali penen saja yaitu selama 27,3 hari, dimana hari pertama rata-rata memerlukan waktu 22,0 hari dan hari kedua yaitu 5,3 hari. Sedangkan rata-rata perlakuan untuk media tanam lain, mulai dari yang paling cepat tumbuh masingmasing yaitu sebesar, perlakuan M2 (SDK $1,5 \mathrm{~kg}$, SG $5 \mathrm{~kg}$ dan DP 1,5 kg) yaitu 31,0 hari, M6 (SDK $5 \mathrm{~kg}$, SG 1,5 kg dan DP 1,5 kg) yaitu 31,0 hari, M5 (SDK 5 kg, SG 3 kg tanpa menggunakan media dedak padi) yaitu 35,7 hari, M1( media standar, tanpa pencampuran serasah daun kakao, SG 5 $\mathrm{kg}$ dan DP $3 \mathrm{~kg}$ ) yaitu 41,3 hari dan perlakuan M4 (SDK 2,5 kg, SG 2,5 kg dan DP $3 \mathrm{~kg}$ ) yaitu selama 46,3 hari. Menurut
Sumiati (2005) bahwa semakin cepat penyebaran miselium maka akan semakin cepat pula dalam pembentukan badan buah. Menurut Wiardani (2010) waktu yang dibutuhkan sampai miselium memenuhi baglog berkisar antara $30-50$ hari sedangkan untuk panen pertama umumnya badan buah jamur akan mulai tumbuh 30 hari setelah baglog dibuka.

Hasil analisis statistik menggunakan SPSS pada uji ANOVA diperoleh tingkat signifikansi 0,845 jauh lebih besar dari 0,01 $(\alpha=1 \%)$ artinya, bervariasinya jumlah media (serasah daun kakao, serbuk gergaji dan dedak padi) terhadap waktu panen sangat tidak berpengaruh nyata.

Media Tanam Jamur Tiram berdasarkan Berat Tubuh Buah (g)

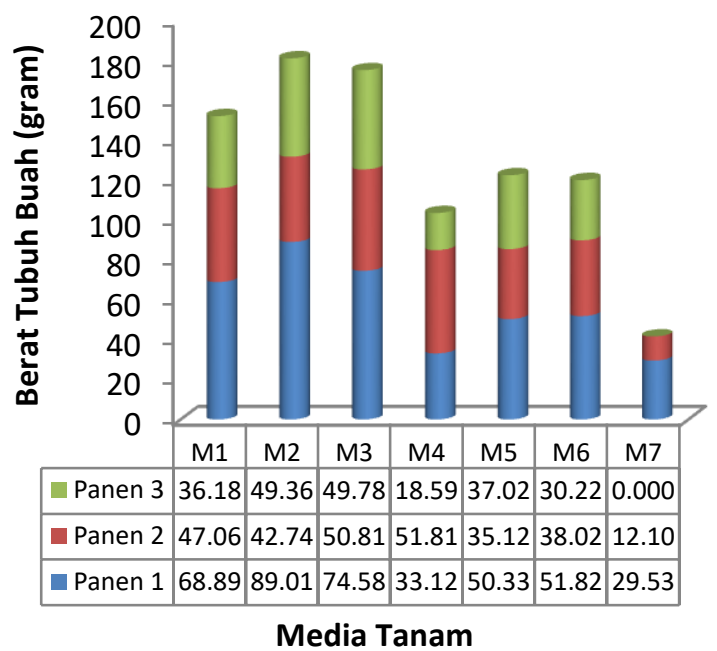

Gambar 2. Berat jamur tiram putih berdasarkan perlakuan media tanam.

Pembentukan tubuh buah jamur tiram putih sebagaimana pada gafik perbandingan nilai rata-rata berat tubuh buah jamur tiram putih (Pleorotus ostreatus) pada setiap perlakuan untuk panen I, II, dan III, menunjukkan perlakuan 
M2 (SDK 1,5 kg, SG $5 \mathrm{~kg}$ dan DP 1,5 kg) merupakan perlakuan terbaik untuk berat tubuh buah dibandingkan perlakuan lainnya, dimana perlakuan M2 diperoleh tubuh buah jamur tiram putih total sebesar $181,122 \mathrm{~g}$, rata-rata setiap kali panen diperoleh sebesar 60,37 g. Sedangkan total produksi kumulatif (untuk 3 kali panen) pada perlakuan yang menggunakan media standar (M1) sebesar 152,145 g. Hasil ini lebih rendah dibandingkan dengan produksi tubuh buah jamur pada perlakuan M2 (SDK 1,5 kg, SG $5 \mathrm{~kg}$ dan DP 1,5 kg). Berdasarkan hal tersebut menunjukkan bahwa serasah daun kakao dapat dimanfaatkan sebagai substrat media tanam untuk pertumbuhan jamur tiram putih. Produksi kumulatif untuk perlakuan yang lain, pada setiap perlakukan berdasarkan yang paling berat yaitu pada perlakuan M3 (SDK $5 \mathrm{~kg}$, SG 1,5 kg dan DP $1,5 \mathrm{~kg}$ ) sebesar 175,182 g, M5 (SDK 5 $\mathrm{kg}$, SG $3 \mathrm{~kg}$ tanpa menggunakan media dedak padi) yaitu sebesar 122,479 g, M6 (SDK $5 \mathrm{~kg}$, SG 1,5 kg dan DP 1,5 kg) yaitu 120,073 g, M4 (SDK 2,5 kg, SG 2,5 kg dan DP $3 \mathrm{~kg}$ ) yaitu 103, $535 \mathrm{~g}$ dan yang paling ringan adalah perlakuan M7 (campuran media tanpa serbuk gergaji di mna serasah daun kakao $5 \mathrm{~kg}$ dan $3 \mathrm{~kg}$ dedak padi) yaitu sebesar 41,639 g.

Hasil analisis statistik menggunakan SPSS pada uji ANOVA diperoleh tingkat signifikansi 0,042 hampir mendekati 0,01 (a $=1 \%$ ) artinya, berfariasinya jumlah media (serasah daun kakao, serbuk gergaji dan dedak padi) terhadap berat tubuh buah berpengaruh sangat nyata.

\section{Perbandingan Kandungan Gizi Jamur Tiram Putih dan Media Jamur Tiram Putih}

Berdasarkan Gambar 3 perbandingan kandungan gizi jamur tiram putih dan media jamur tiram putih, nilai konversi nutrien media menjadi tubuh buah jamur tiram tidak dapat ditentukan secara signifikan, hal ini disebabkan karena pada saat analisis media tanam jamur tiram yang sudah panen, miselia yang ada dalam media tidak dapat di pisahkan karena ukurannya yang kecil dan hampir menyerupai bentuk media.

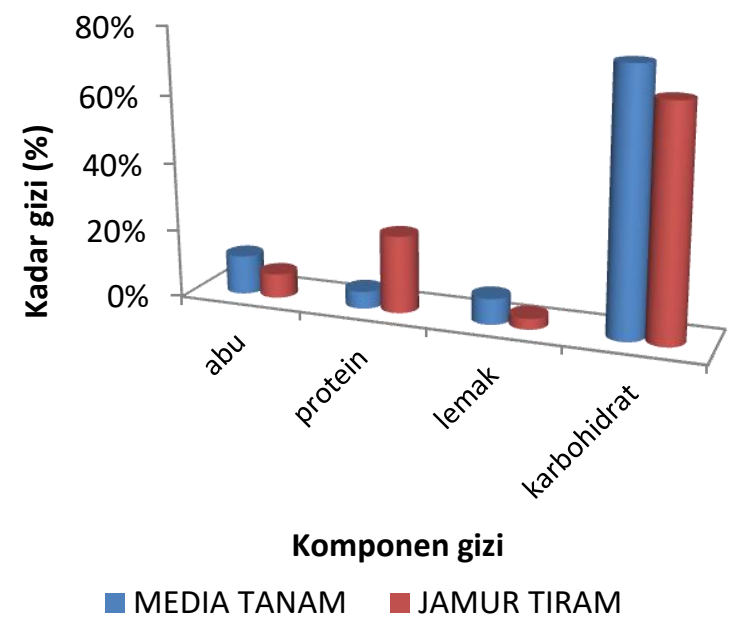

Gambar 3. Perbandingan kandungan gizi jamur tiram dan media tanam jamur tiram.

Berdasarkan nilai korelasi kandungan gizi jamur tiram dan media tanam jamur tiram putih untuk protein $r=0,64$, yang artinya korelasinya kuat karena kedua variabel mempunyai hubungan searah. Begitupun dengan lemak nilai korelasinya tidak jauh beda dengan protein yaitu $r=$ 0,62 . Sedangkan untuk karbohidrat dan 
abu tidak berpengaruh terhadap kandungan gizinya, dimana nilai korelasi karbohidrat $r=-0,25$ dan abu $r=-0,74$ yang artinya tidak ada korelasi antara dua variabel. Hal ini sesuai dengan peryataan Sarwono (2006), dimana nilai 0 : Tidak ada korelasi antara dua variabel dan nilai $>0,5$ $-0,75$ : korelasi kuat.

Perbandingan karbohidrat media dengan jamur sangat berbeda jauh, di mana pada media kandungan karbohidrat lebih banyak dibandingkan pada jamur tiram.Hal ini sesuai dengan Pada pembudidayaan jamur tiram dibutuhkan media yang cocok agar didapatkan hasil produksi yang maksimal.Terdapat beberapa kandungan hara yang dibutuhkan oleh jamur tiram untuk pertumbuhan yaitu lignin, karbohidrat (selulosa dan glukosa), protein, nitrogen, serat, $\mathrm{P}$ (fosfor), $\mathrm{K}$ (kalium), Ca (kalsium) dan vitamin (Cahyana, 2004).Faktor lain selain unsur hara yang mempengaruhi tumbuhnya jamur tiram putih, adalah suhu, kelembapan, intensitas cahaya dan $\mathrm{pH}$ (Shim, 2001).

Media tanam Pleurotus ostreatus yang mengandung lignin atau serat kasar, selulosa, karbohidrat, dan serat yang dapat didegradasi oleh jamur menjadi karbohidrat yang kemudian dapat digunakan untuk sintesis protein (Alex, 2011). Seperti pada penelitian Hale (2010), media tanam jamur tiram putih menggunakan serbuk gergaji kayu sengon (Albizzia faltata backer) yang dicampur dengan kertas koran dapat meningkatkan kadar protein jamur tiram putih, karena di dalam serbuk gergaji kayu sengon dan kertas koran mengandung lignin, selulosa, N (Nitrogen), kadar air, hemiselusa, dan unsur yang diendapkan.

Dalam proses pengomposan terdapat proses dekomposisi yang kerjanya melepaskan senyawa $\mathrm{N}, \mathrm{P}, \mathrm{K}, \mathrm{Ca}, \mathrm{Mg}, \mathrm{S}$ dan unsur mikro (Rosmarkam dan Nasid, 2011). Menurut Hardjowigeno (2003) dalam Wasis\& Nur (2011), fungsi nitrogen sebagai pupuk adalah untuk memperbaiki vegetatif tanaman dan membantu proses pembentukan protein. Unsur kalium berfungsi membantu pembentukan protein dan karbohidrat, memperkuat jaringan tanaman serta membentuk antibodi tanaman melawan penyakit dan kekeringan (Wasis \& Nur, 2011).

\section{KESIMPULAN}

Serasah daun kakao dapat digunakan sebagai media tanam jamur tiram putih, dapat dilihat dari setiap perlakuan untuk panen I, II, dan III, menunjukkan perlakuan M2 (SDK 1,5 kg, SG $5 \mathrm{~kg}$ dan DP 1,5 kg) merupakan perlakuan terbaik untuk berat tubuh buah dibandingkan perlakuan lainnya, dimana perlakuan M2 diperoleh tubuh buah jamur tiram putih total sebesar $181,122 \mathrm{~g}$, rata-rata setiap kali panen diperoleh sebesar $60,3740 \mathrm{~g}$.

\section{DAFTAR PUSTAKA}

Alexs M. 2011. Untung Besar Budi Daya Aneka Jamur .Yokyakarta: Pustaka Baru Press.

Andarwulan N., F. Kusnandar, D. Herawati. 2011. Analisis Pangan. Jakarta: Dian Rakyat. 
Ambarwati H.T. 1991. Budidaya jamur tiram putih (pleurotus ostretus) pada jerami.Biologi. 1(1): 1-11.

Cahyana, Muchroji,Bakrun M. 1997. Jamur Tiram. Jakarta:Penebar Swadaya.

Chazali, Syammahfuz, PS Pratiwi. 2009. Usaha Jamur Tiram Skala Rumah Tangga. Jakarta: Penebar Swadaya.

Hale, Adeodata I. 2010. Kandungan Protein Dan Mineral Jamur Tiram Putih (Pleurotus Ostreatus) Pada Serbuk Gergaji Kayu Sengon (Albizzia Faltata Backer), Kayu Jati (Tectona Grandis L.F.) Dan Kertas Koran. [Skripsi]. Yogyakarta: Program Studi Biologi Fakultas Teknobiologi Universitas Atma Jaya.

Parjimo, Andoko A. 2007. Budi Daya Jamur. Jakarta: Agomedia Pustaka.

Rosmarkam, Afandie, Yuwono NW. 2011. IImu Kesuburan Tanah. Yogyakarta: Kanisius.

Sarwono.2006. Metodologi Penelitian Kuantitatif dan Kualitatif. Yogyakarta: Graha IImu.

Shim M.S. 2001. Physiology Of Substrate Fermentation And Substrate Making. Mushroom Sci. 12(2):207-218.

Sumiati E., Suryaningsih E., Puspitasari. 2005. Perbaikan Jamur Tiram Putih Pleurotus ostreatus Strain Florida dengan Modifikasi Bahan Baku Utama Substrat.J. Hort. 16 (2): 96-17.

Sulistyowati E., Junianto Y.D. Mufrihati E., WahabA. 2003. Keefektifan jamur Paecylomices fumosoroseus untuk mengendalikan Penggerek Buah Kakao (Conopomorhpa cramerella Snell.). Pelita Perkebunan. 18: 120128.

Suriawiria U. 1986.Pengantar Untuk Mengenal Jamur dan Menanam Jamur. Bandung: Angkasa Bandung.
Wahyudi T.H., Syarief, UntungS. 2002. Pengaruh macam serbuk gergaji terhadap produksi dan kandungan nutrisi tiga jenis jamur kayu. Tropika. 10(1):79-86.

Wasis Basuki, NurF. 2011. Pengaruh Pupuk Npk Terhadap Pertumbuhan Semai Gmelina (Gmelina arborea Roxb.) 1: $14-18$.

Wiardani, I. 2010. Budidaya Jamur Konsumsi. Yogyakarta: Lily Publisher.

Zadrazil F. 1978. Cultivationof of Pleurotus in the biology and cultivation og edible mushroom. UK: Academic Press Inc.

Zuhra, Sofyana, Cutyana. 2012. Pengaruh Kondisi Operasi Alat Pengering Semprot Terhadap Kualitas Susu Bubuk Jagung. Jurnal Rekayasa Kimia dan Lingkungan. 9(1): 36-44. 